\title{
TETRAPOD EXTINCTIONS DURING THE LATE TRIASSIC: EVIDENCE FROM THE WESTERN UNITED STATES
}

HUNT*, Adrian P. and LUCAS, Spencer G., New Mexico Museum of Natural History, 1801 Mountain Road N. W., Albuquerque, NM 87104 U.S. A.

Most recent workers have identified a major extinction of nonmarine tetrapods during the Late Triassic at the Carnian-Norian boundary. However, this identification is based principally on the stratigraphic distribution of tetrapods where there either is a major facies change at the Carnian-Norian boundary (Germany) or a significant unconformity that spans much of the early Norian (Argentina). Instead, we have examined the stratigraphic record of tetrapods in the western United States (Chinle Group) where there is a relatively continuous, nonmarine depositional and fossil record across the Carnian-Norian boundary that does not encompass major facies changes. The Chinle Group, because of its great area of exposure, more than one century of extensive collection and relatively complete publication, contains the world's best record of tetrapods across the Carnian-Norian boundary.

The tetrapod record from the Chinle Group does not record a significant tetrapod extinction at the Carnian-Norian boundary. Instead, it documents a staggered extinction of some taxa during the late Carnian and the persistence of most taxa across the CarnianNorian boundary. Thus, rhynchosaurs become extinct at the end of the early-late Carnian, whereas dicynodonts become extinct somewhat later, during the latest Carnian. Among metoposaurids, only the large taxa (Buettneria) disappear at the end of the Carnian. Other groups - phytosaurs, aetosaurs, rauisuchians, trilophosaurs, etc. - only exhibit some generic turnover at the Carnian-Norian boundary. The first appearance of dinosaurs, linked by some to a Carnian-Norian tetrapod extinction, is well in advance of the end of the Carnian. Thus, we conclude that the highest resolution tetrapod record of the late Carnian and early Norian does not document a significant tetrapod extinction at the end of the Carnian. 